\title{
Characterization of the self-perception of oral health in the Brazilian adult population
}

\author{
Caracterização da condição percebida de saúde bucal na população \\ adulta brasileira
}

Danielle Bordin (https://orcid.org/0000-0001-7861-0384) ${ }^{1}$

Cristina Berger Fadel (https://orcid.org/0000-0002-7303-5429) ${ }^{2}$

Suzely Adas Saliba Moimaz (https://orcid.org/0000-0002-4949-529X) ${ }^{3}$

Celso Bilynkievycz dos Santos (https://orcid.org/0000-0003-2107-8299) ${ }^{4}$

Cléa Adas Saliba Garbin (https://orcid.org/0000-0001-5069-8812) ${ }^{3}$

Nemre Adas Saliba (https://orcid.org/0000-0001-9608-1631) ${ }^{3}$
${ }^{1}$ Departamento de Enfermagem e Saúde Pública, Universidade Estadual de Ponta Grossa (UEPG). Av. Valério Ronchi 160, Uvaranas. 84030-320 Ponta Grossa PR Brasil. daniellebordin@ hotmail.com

${ }^{2}$ Departamento de Odontologia, UEPG. Ponta

Grossa PR Brasil.

${ }^{3}$ Departamento de

Odontologia Infantil e Social, Universidade Estadual Paulista Júlio de Mesquita Filho. Araçatuba SP Brasil.

${ }^{4}$ Setor de Ciências Biológicas e da Saúde, UEPG. Ponta Grossa PR Brasil.

\begin{abstract}
This article aims to perform an analysis of the factors that determine the self-perception of oral health of Brazilians, based on a multidimensional methodology basis. This is a cross-sectional study with data from a national survey. A household interview was conducted with a sample of 60,202 adults. Self-perception of oral health was considered the outcome variable and sociodemographic characteristics, self-care and oral health condition, use of dental services, general health and work condition as independent variables. The dimensionality reduction test was used and the variables that showed a relationship were submitted to logistic regression. The negative oral health condition was related to difficulty feeding, negative evaluation of the last dental appointment, negative self-perception of general health condition, not flossing, upper dental loss, and reason for the last dental appointment. The use of a multidimensional methodological basis was able to design explanatory models for the self-perception of oral health of Brazilian adults, and these results should be considered in the implementation, evaluation, and qualification of the oral health network.
\end{abstract}

Key words Oral Health, Perception, Selfevaluation, Cross-Sectional Studies, Data Mining
Resumo $O$ objetivo deste artigo é realizar uma análise dos fatores que determinam a autopercepção de saúde bucal dos brasileiros sob base metodológica multidimensional. Estudo transversal, com dados provenientes de inquérito em âmbito nacional. Foi realizada entrevista domiciliar com uma amostra de 60.202 adultos. Considerou-se a autopercepção de saúde bucal como variável desfecho e características sociodemográficas, de autocuidado e condição de saúde bucal, de utilização de serviços odontológicos, de condição de saúde geral e de trabalho como variáveis independentes. Empregou-se o teste de redução de dimensionalidade e as variáveis que apresentaram relação passaram pelo teste de regressão logística. A autopercepção negativa de saúde bucal apresentou-se relacionada à dificuldade para se alimentar, avaliação negativa do atendimento recebido durante a última consulta odontológica, autopercepção ruim da condição de saúde geral, não utilização de fio dental, perda dental superior e motivo da última consulta com o cirurgião dentista. A utilização de base metodológica multidimensional foi capaz de (re)desenhar modelos explicativos para a condição percebida de saúde bucal de adultos brasileiros, devendo, os seus resultados serem considerados na implementação, avaliação e qualificação da rede de saúde bucal.

Palavras-chave Saúde bucal, Percepção, Autoavaliação, Estudos transversais, Mineração de dados 


\section{Introduction}

The personal assessment of living and becoming ill is characterized by the interpretation that an individual performs on his/her own health ${ }^{1,2}$. Several factors have been pointed out in the literature as capable of influencing this self-assessment: personal characteristics, especially the access to information $^{3}$, demographic aspects ${ }^{4-12}$, level of acculturation $^{4,6}$, beliefs, values, health practices ${ }^{3,6,13}$, physical and cognitive ability, and emotional relationships ${ }^{14,15}$.

Due to the subjective nature of the object, classical epidemiological studies are not able to apprehend the elements that are related to the evaluation of the health status of the individuals, since they are mainly devoted to aspects of human biology, clinical, and laboratorial methods. Although biologically based information is essential for the quantification of the population health conditions, since they subsidize the planning, organization, and monitoring of health services, personal measures are increasingly recommended by the World Health Organization ${ }^{16}$. Authors affirm that through these measures the individual conscience on health status is reflected ${ }^{17}$, constituting also an important contribution to the orientation of political and social decisions that have as a goal the quality of life ${ }^{3,6}$ and to increase the search, adherence, and motivation of individuals for treatment and self-care ${ }^{4}$.

In the oral health field in Brazil, despite the importance of assessing patients' self-perception on broad and effective bases, most studies have focused on isolated conditions such as clinical (use of dental prosthesis, cavities, and periodontal disease), socioeconomic (income and level of education), socio-demographic (gender, age, and ethnicity), and behavioral factors (consumption of tobacco, alcohol, and other drugs), as well as specific habits of oral hygiene ${ }^{3-12,18}$.

The empirical evaluation of self-perception of oral health should incorporate as many critical, social, and biological indicators as possible, aiming at the formation of a synthesis measure, influenced in a micro and macro dimensional way, with repercussions on people's quality of life ${ }^{6}$.

Few studies on the self-perception of oral health consider representative samples of the entire country ${ }^{11}$, and this fact precludes the access of formulators and implementers of public policies to a true and near panorama of the evaluation of the health conditions of individuals and collectivities.
Thus, the objective of the present study was to perform a more comprehensive analysis of the factors that determine self-perception of oral health of Brazilians, based on a multidimensional methodological basis.

It is believed that the results of this study will contribute to the effectiveness of evaluation and planning of public oral health actions, making it possible to resize and qualify them.

\section{Methods}

This is a cross-sectional quantitative study with data from the population-based survey - National Health Survey (NHS), proposed by the Ministry of Health and conducted in 2013 by the Brazilian Institute of Geography and Statistics $(\mathrm{IBGE})^{19}$.

\section{The National Health Survey}

The research is in a household level and the sampling plan used was based on a cluster sampling in three stages, with the sectors or groups of census tracts being the primary sampling units, the households the secondary, and the selected elderly inhabitants, the tertiary units ${ }^{19}$.

The sample size was defined considering the level of precision desired for the estimates of some indicators of interest, resulting in a sample of 60,202 adults interviewed ${ }^{19}$. Details on the sampling and weighting process are available in the PNS report ${ }^{19}$.

Previously calibrated researchers collected the data. The information was obtained through individual interviews and stored on handheld computers. Only individuals older than 18 years old participated in the research. The interview was directed by three forms: the domicile, referring to the characteristics of the house; the residents of the house; and the individual, answered by a drawn resident of the house ${ }^{19}$. For the present study it was considered exclusively the data of the drawn resident from the last two forms.

The survey was approved by the National Commission for the Protection of Human Subjects of the Ministry of Health. The data used are in the public domain from the National Health Survey. Being the data available without link: http://www.pns.icict.fiocruz.br/index.php? $\mathrm{pa}=$ resultados. 


\section{Treatment and data analysis}

The outcome variable "self-perception of oral health" is the result of the question: In general, how do you evaluate your oral health (teeth and gums)? Possible answers were: very good, good, regular, poor and very poor. For the purpose of analysis in the present study, the responses were grouped into positive (very good and good) and negative (regular, poor and very poor).

In the exploration phase of the data, 47 variables of interest were cataloged in order to compose the independent variables, related to: sociodemographic characteristics (eight variables); oral self-care (five variables); oral health condition (five variables); use of dental services (five variables); general health condition (eighteen variables); job characteristics (six variables).

In order to verify the existence of one or more chronic diseases, regardless of the disease installed, a new variable grouping all the diseases listed above was created, entitled "presence of one or more chronic diseases."

The variable 'number of natural teeth present in the mouth' was also developed. For that, it was subtracted the number of upper and lower teeth lost from all natural teeth $(\mathrm{n}=32)$. Subsequently, the variable was categorized, according to a previous study, into more than 10 natural teeth present and 10 natural teeth present or less 8 .

After the complete database treatment, dimensionality reduction was performed using the Correlation-based Feature Selection (CFS) algorithm using the 10 -fold cross validation technique. This data mining test is recommended to be used in a large set of data and variables as proposed in the present study. It evaluated, according to response patterns, the entire data set and the 47 variables at a single time to look for variables highly related to the outcome variable and not related to each other. In this way, it does not only consider the utility of variables individually, but also the correlation level between them, thereby eliminating any and all confounding relationships. The variables with nonexistent or weak and/or redundant relations, which do not bring information gain to the model, are all eliminated by the algorithm, without needing any researcher's influence.

Thus, it is possible to validate the pure and strict relations of the independent variables to the outcome variable with much more precision than other tests commonly used in the literature.

After, the variables related to 'Self-perception of oral health' were evaluated through logistic regression to measure the magnitude of the associations.
The model had an explanatory capacity of $73 \%$. All analyzes were performed using the software WEKA (Waikato Environment for Knowledge Analysis) environment.

The WEKA software does not report the individual confidence intervals and $p$ values for each OR; it considers the default values of $95 \%$ confidence interval and $p$ value $<0.05$. In this type of analysis, the possibility of influencing the confidence interval due to the sample size is eliminated in the steps preceding the regression analysis.

\section{Results}

The descriptive analysis shows that about $34 \%$ of the individuals interviewed evaluated their oral health negatively (Table 1). In the results of the attribute selection analysis, it was verified that the variables most strongly related to self-perception of oral health were: difficulty feeding, upper dental loss, self-perception of the general health condition, evaluation of the last dental appointment, reason for last dental appointment and flossing. No variables related to sociodemographic and job characteristics were related to self-perception of health.

Table 1 shows the distribution of adults, considering the variables used in the study that did not present a strong relation with the dependent variable. Table 2 also describes the sample according to the independent variables that presented a relation with the self-perception of oral health. Table 3 shows the reasons for the chance of reporting negative oral health status according to independent variables.

The variable that most influenced the evaluation of oral health was the difficulty in feeding, where individuals who reported difficulty (11\%) presented 5.81 more chance of having a poor perception of health in detriment to those without difficulty. The upper tooth loss was also linked to self-perception of health. The partial loss of upper teeth increases the probability of having a negative perception of oral health in 1.49 , while the total loss of teeth was shown to be a protective factor $(\mathrm{OR}=0.86)$.

Individuals who negatively evaluated their overall health (49\%), presented 1.91 more chance of evaluating their oral health as bad. Regarding to the use of dental services, the search for dental consultations for reasons other than prevention (treatment or others) and negative evaluation of care increases the chances of the individual to have a negative perception of oral health.

Still, most of the individuals reported using dental floss, this condition linked to a good per- 
Table 1. Descriptive analysis of the independent variables that do not presented a relation with the selfperception of oral health. Brazil, $2013(n=60202)$.

\begin{tabular}{|c|c|c|c|c|c|c|c|}
\hline \multirow[t]{2}{*}{ Variables } & \multirow[t]{2}{*}{ Class } & \multicolumn{2}{|c|}{ Total } & \multicolumn{2}{|c|}{$\begin{array}{c}\text { Positive } \\
\text { Perception }\end{array}$} & \multicolumn{2}{|c|}{$\begin{array}{c}\text { Negative } \\
\text { Perception }\end{array}$} \\
\hline & & $\mathbf{n}$ & $\%$ & n & $\%$ & n & $\%$ \\
\hline \multicolumn{2}{|c|}{ Self-perception of oral health } & 60202 & 100 & 39572 & 66 & 20630 & 34 \\
\hline \multicolumn{8}{|c|}{ Sociodemographic Characteristics } \\
\hline \multirow[t]{2}{*}{ Gender } & Male & 25920 & 43 & 16570 & 64 & 9350 & 36 \\
\hline & Fame & 34282 & 57 & 23002 & 67 & 11280 & 33 \\
\hline \multirow[t]{6}{*}{ Age } & 18 a 30 & 15750 & 26 & 11309 & 72 & 4441 & 28 \\
\hline & 31 a 40 & 14139 & 23 & 9629 & 68 & 4510 & 32 \\
\hline & 41a 50 & 11160 & 19 & 7075 & 63 & 4085 & 37 \\
\hline & 51 a 60 & 10426 & 17 & 5279 & 51 & 5147 & 49 \\
\hline & More than 60 & 8727 & 14 & 6280 & 72 & 2447 & 28 \\
\hline & Negative & 21061 & 35 & 10226 & 49 & 10835 & 51 \\
\hline \multirow{6}{*}{$\begin{array}{l}\text { Skin color/ } \\
\text { ethnicity }\end{array}$} & White & 24106 & 40 & 17183 & 71 & 6923 & 29 \\
\hline & Black & 5631 & 9 & 3411 & 61 & 2220 & 39 \\
\hline & Asian & 533 & 1 & 344 & 65 & 189 & 35 \\
\hline & Mixed-race & 29512 & 49 & 18390 & 62 & 11122 & 38 \\
\hline & Indian & 417 & 1 & 242 & 58 & 175 & 42 \\
\hline & Ignored & 03 & 0 & 2 & 67 & 1 & 33 \\
\hline \multirow[t]{2}{*}{ Live with spouse } & Yes & 34522 & 57 & 22433 & 65 & 12089 & 35 \\
\hline & No & 25680 & 43 & 17139 & 67 & 8541 & 33 \\
\hline \multirow[t]{4}{*}{ Marital status } & Married & 23741 & 39 & 15800 & 67 & 7941 & 33 \\
\hline & Separated or Divorced & 4727 & 8 & 3186 & 67 & 1541 & 33 \\
\hline & Widowed & 4708 & 8 & 2899 & 62 & 1809 & 38 \\
\hline & Single & 27026 & 45 & 17687 & 65 & 9339 & 35 \\
\hline \multirow[t]{2}{*}{ Literacy } & Yes & 54335 & 90 & 36638 & 67 & 17697 & 33 \\
\hline & No & 5867 & 10 & 2934 & 50 & 2933 & 50 \\
\hline \multirow[t]{6}{*}{ Level of education } & Literate & 7630 & 13 & 4337 & 57 & 3293 & 43 \\
\hline & Elementary school & 15288 & 25 & 8979 & 59 & 6309 & 41 \\
\hline & High School & 18589 & 31 & 12849 & 69 & 5740 & 31 \\
\hline & University & 8109 & 13 & 6499 & 80 & 1610 & 20 \\
\hline & Postgraduate & 487 & 1 & 417 & 86 & 70 & 14 \\
\hline & Did not answer & 10099 & 17 & 6491 & 64 & 3608 & 36 \\
\hline \multirow[t]{5}{*}{ Region of residence } & North & 12536 & 21 & 7830 & 62 & 4706 & 38 \\
\hline & Northeast & 18305 & 30 & 10861 & 59 & 7444 & 41 \\
\hline & Southeast & 14294 & 24 & 10167 & 71 & 4127 & 29 \\
\hline & South & 7548 & 13 & 5476 & 73 & 2072 & 27 \\
\hline & Midwest & 7519 & 12 & 5238 & 70 & 2281 & 30 \\
\hline \multicolumn{8}{|c|}{ Oral Health Condition } \\
\hline \multirow[t]{3}{*}{ Lower dental loss } & None & 21133 & 35 & 16571 & 78 & 4562 & 22 \\
\hline & Some & 32121 & 53 & 18625 & 58 & 13496 & 42 \\
\hline & All teeth missing & 6948 & 12 & 4376 & 63 & 2572 & 37 \\
\hline \multirow{2}{*}{$\begin{array}{l}\text { Number of natural } \\
\text { teeth present }\end{array}$} & None & 10019 & 17 & 5907 & 59 & 4112 & 41 \\
\hline & $>10$ & 50183 & 83 & 33665 & 67 & 16518 & 33 \\
\hline \multirow{4}{*}{$\begin{array}{l}\text { Use of dental } \\
\text { prosthesis }\end{array}$} & $\leq 10$ & 24431 & 41 & 14269 & 58 & 10162 & 42 \\
\hline & No & 14932 & 25 & 8970 & 60 & 5962 & 40 \\
\hline & $\begin{array}{l}\text { Yes, but needs to replace some } \\
\text { teeth }\end{array}$ & 5558 & 9 & 3668 & 66 & 1890 & 34 \\
\hline & Yes, but needs to replace all teeth & 15281 & 25 & 12665 & 83 & 2616 & 17 \\
\hline
\end{tabular}


Table 1. Descriptive analysis of the independent variables that do not presented a relation with the selfperception of oral health. Brazil, $2013(n=60202)$.

\begin{tabular}{|c|c|c|c|c|c|c|c|}
\hline \multirow[t]{2}{*}{ Variables } & \multirow[t]{2}{*}{ Class } & \multicolumn{2}{|c|}{ Total } & \multicolumn{2}{|c|}{$\begin{array}{c}\text { Positive } \\
\text { Perception }\end{array}$} & \multicolumn{2}{|c|}{$\begin{array}{c}\text { Negative } \\
\text { Perception }\end{array}$} \\
\hline & & $\mathbf{n}$ & $\%$ & $\mathbf{n}$ & $\%$ & $\mathbf{n}$ & $\%$ \\
\hline \multicolumn{2}{|c|}{ Self-perception of oral health } & 60202 & 100 & 39572 & 66 & 20630 & 34 \\
\hline \multicolumn{8}{|c|}{ General Health Condition } \\
\hline \multirow{2}{*}{$\begin{array}{l}\text { Difficulty getting } \\
\text { around }\end{array}$} & Yes & 1567 & 3 & 811 & 52 & 756 & 48 \\
\hline & No & 58635 & 97 & 38761 & 66 & 19874 & 34 \\
\hline \multirow[t]{2}{*}{ Difficulty seeing } & Yes & 23859 & 40 & 15951 & 67 & 7908 & 33 \\
\hline & No & 36343 & 60 & 23621 & 65 & 12722 & 35 \\
\hline \multirow{2}{*}{$\begin{array}{l}\text { Consume alcoholic } \\
\text { drinks }\end{array}$} & Yes & 23002 & 38 & 15332 & 67 & 7670 & 33 \\
\hline & No & 37200 & 62 & 24240 & 65 & 12960 & 35 \\
\hline \multirow{2}{*}{$\begin{array}{l}\text { Perform physical } \\
\text { activity }\end{array}$} & Yes & 17896 & 30 & 13189 & 74 & 4707 & 26 \\
\hline & No & 42306 & 70 & 26383 & 62 & 15923 & 38 \\
\hline \multirow[t]{2}{*}{ Use tobacco } & Yes & 8729 & 14 & 4853 & 56 & 3876 & 44 \\
\hline & No & 51473 & 86 & 34719 & 67 & 16754 & 33 \\
\hline \multirow{2}{*}{$\begin{array}{l}\text { Presence of any } \\
\text { chronic, physical or } \\
\text { mental illness }\end{array}$} & Yes & 27250 & 45 & 22983 & 84 & 4267 & 16 \\
\hline & No & 32952 & 55 & 16589 & 50 & 16363 & 50 \\
\hline \multicolumn{8}{|l|}{ Use of dental services } \\
\hline \multirow{4}{*}{$\begin{array}{l}\text { Time since } \\
\text { the last dental } \\
\text { appointment }\end{array}$} & In the last 12 months & 25656 & 43 & 18688 & 73 & 6968 & 27 \\
\hline & Over 1 and under 2 years & 11518 & 19 & 7622 & 66 & 3896 & 34 \\
\hline & Over 2 years & 20942 & 35 & 12162 & 58 & 8780 & 42 \\
\hline & Never went to the dentist & 2086 & 3 & 1100 & 53 & 986 & 47 \\
\hline \multirow{4}{*}{$\begin{array}{l}\text { Duration of dental } \\
\text { appointment }\end{array}$} & $\leq 30$ minutes & 17088 & 28 & 12274 & 72 & 4814 & 28 \\
\hline & $30<61$ minutes & 7439 & 12 & 5648 & 76 & 1791 & 24 \\
\hline & $>60$ minutes & 1129 & 2 & 766 & 68 & 363 & 32 \\
\hline & Not applicable & 34546 & 57 & 20884 & 60 & 13662 & 40 \\
\hline \multirow{4}{*}{$\begin{array}{l}\text { The dental } \\
\text { appointment by }\end{array}$} & Health Insurance & 4744 & 8 & 3835 & 81 & 909 & 19 \\
\hline & Private & 14042 & 23 & 10647 & 76 & 3395 & 24 \\
\hline & SUS & 6451 & 11 & 3947 & 61 & 2504 & 39 \\
\hline & Did not know/Not answered & 34965 & 58 & 20884 & 60 & 14081 & 40 \\
\hline \multirow{3}{*}{$\begin{array}{l}\text { Individual health } \\
\text { insurance }\end{array}$} & Yes & 4744 & 8 & 3835 & 10 & 909 & 4 \\
\hline & No & 20912 & 35 & 14853 & 38 & 6059 & 29 \\
\hline & Not answered & 34546 & 57 & 20844 & 53 & 13662 & 66 \\
\hline \multicolumn{8}{|l|}{ Oral Self-care } \\
\hline \multirow[t]{5}{*}{ Brushing frequency } & Never brushed & 132 & 0 & 58 & 44 & 74 & 56 \\
\hline & Does not brush every day & 520 & 1 & 191 & 37 & 329 & 63 \\
\hline & Once a day & 4791 & 8 & 2229 & 47 & 2562 & 53 \\
\hline & Twice a day or more & 53594 & 89 & 36575 & 68 & 17019 & 32 \\
\hline & Not answered & 1165 & 2 & 519 & 45 & 646 & 55 \\
\hline \multirow[t]{3}{*}{ Toothbrush } & Yes & 58719 & 98 & 38902 & 66 & 19817 & 34 \\
\hline & No & 186 & 0 & 93 & 50 & 93 & 50 \\
\hline & Not answered & 1297 & 2 & 577 & 44 & 720 & 56 \\
\hline \multirow[t]{3}{*}{ Toothpaste } & Yes & 58669 & 97 & 38874 & 66 & 19795 & 34 \\
\hline & No & 236 & 0 & 121 & 51 & 115 & 49 \\
\hline & Not answered & 1297 & 2 & 577 & 44 & 720 & 56 \\
\hline Toothbrush & Less than 3 months & 27958 & 46 & 19590 & 70 & 8368 & 30 \\
\hline replacement & More than 3 months & 30947 & 51 & 19405 & 63 & 11542 & 37 \\
\hline frequency & Not answered & 1297 & 2 & 577 & 44 & 720 & 56 \\
\hline
\end{tabular}


Table 1. Descriptive analysis of the independent variables that do not presented a relation with the selfperception of oral health. Brazil, $2013(n=60202)$.

\begin{tabular}{|c|c|c|c|c|c|c|c|}
\hline \multirow[t]{2}{*}{ Variables } & \multirow[t]{2}{*}{ Class } & \multicolumn{2}{|c|}{ Total } & \multicolumn{2}{|c|}{$\begin{array}{c}\text { Positive } \\
\text { Perception }\end{array}$} & \multicolumn{2}{|c|}{$\begin{array}{c}\text { Negative } \\
\text { Perception }\end{array}$} \\
\hline & & $\mathbf{n}$ & $\%$ & $\mathbf{n}$ & $\%$ & $\mathbf{n}$ & $\%$ \\
\hline \multicolumn{2}{|c|}{ Self-perception of oral health } & 60202 & 100 & 39572 & 66 & 20630 & 34 \\
\hline \multicolumn{8}{|c|}{ Work characteristics } \\
\hline \multirow[t]{2}{*}{ Has a paid job } & Yes & 33990 & 56 & 23289 & 69 & 10701 & 31 \\
\hline & No & 26212 & 44 & 16283 & 62 & 9929 & 38 \\
\hline \multirow[t]{7}{*}{ Occupation } & Domestic Work & 2784 & 5 & 1640 & 59 & 1144 & 41 \\
\hline & Private sector employee & 16267 & 27 & 11567 & 71 & 4700 & 29 \\
\hline & Public sector employee & 5841 & 10 & 4416 & 76 & 1425 & 24 \\
\hline & Employer & 1023 & 2 & 791 & 77 & 232 & 23 \\
\hline & Free-lancer & 10092 & 17 & 6150 & 61 & 3942 & 39 \\
\hline & Unpaid worker & 435 & 1 & 276 & 63 & 159 & 37 \\
\hline & Not answered & 23760 & 39 & 14732 & 62 & 9028 & 38 \\
\hline \multirow[t]{3}{*}{ Number of jobs } & One & 34776 & 58 & 23671 & 68 & 11105 & 32 \\
\hline & Two or more & 1666 & 3 & 1169 & 70 & 497 & 30 \\
\hline & Not applicable & 23760 & 39 & 14732 & 62 & 9028 & 38 \\
\hline \multirow[t]{5}{*}{ Income } & $\leq 216$ dollars & 11661 & 19 & 6840 & 59 & 4821 & 41 \\
\hline & $216>421$ dollars & 12319 & 20 & 8364 & 68 & 3955 & 32 \\
\hline & $420>841$ dollars & 6988 & 12 & 5174 & 74 & 1814 & 26 \\
\hline & $>840$ dollars & 5027 & 8 & 4175 & 83 & 852 & 17 \\
\hline & Not applicable & 24207 & 40 & 15019 & 62 & 9188 & 38 \\
\hline \multirow{4}{*}{$\begin{array}{l}\text { Number of hours } \\
\text { worked per week }\end{array}$} & $\geq 20$ hours & 4264 & 7 & 2247 & 53 & 2017 & 47 \\
\hline & $20>41$ hours & 16576 & 28 & 10609 & 64 & 5967 & 36 \\
\hline & $>40$ hours & 15602 & 26 & 10132 & 65 & 5470 & 35 \\
\hline & Not applicable & 23760 & 39 & 16584 & 70 & 7176 & 30 \\
\hline \multirow[t]{3}{*}{ Works at night } & Yes & 5419 & 9 & 3795 & 70 & 1624 & 30 \\
\hline & No & 31023 & 52 & 21045 & 68 & 9978 & 32 \\
\hline & Not applicable & 23760 & 39 & 14732 & 62 & 9028 & 38 \\
\hline
\end{tabular}

ceived oral health condition, with those who did not use it, 1.88 more likely to present negative oral health perception.

\section{Discussion}

The variables most strongly related to the self-perception of oral health found in the study were: difficulty feeding, upper dental loss, self-perception of the general health condition, evaluation of the last dental appointment, reason for last dental appointment and flossing. Thus, it can be inferred that subjective conditions, which evaluate human experiences and health, are much more capable of explaining the variability of self-perception of oral health than objective measures, which mostly measure the context of the presence of diseases ${ }^{11,20,21}$.

According to studies ${ }^{5,8,20,22,23}$, individuals who report more dysfunctions, symptoms, and oral incapacities evaluate their oral health in a more negative way, in line with the findings of the present study, which demonstrate that difficulty feeding increases by 5.8 times the chance of the individual exhibiting a negative self-perception of oral health. These results may reflect the relation between masticatory limitation and the worsening of the psychosocial conditions by the embarrassment to feed in front of other people, or on physical or functional conditions, especially as the nuisance when swallowing food ${ }^{5}$.

The literature shows that the number of teeth present in the mouth is an important determi- 
Table 2. Descriptive analysis of the independent variables that presented a relation with the self-perception of oral health. Brazil, 2013 ( $n=60202)$.

\begin{tabular}{|c|c|c|c|c|c|c|c|}
\hline \multirow[t]{2}{*}{ Variables } & \multirow[t]{2}{*}{ Class } & \multicolumn{2}{|c|}{ Total } & \multicolumn{2}{|c|}{$\begin{array}{c}\text { Positive } \\
\text { Perception }\end{array}$} & \multicolumn{2}{|c|}{$\begin{array}{c}\text { Negative } \\
\text { Perception }\end{array}$} \\
\hline & & $\mathbf{n}$ & $\%$ & $\mathbf{n}$ & $\%$ & $\mathbf{n}$ & $\%$ \\
\hline \multicolumn{8}{|l|}{ Oral Health Condition } \\
\hline \multirow[t]{2}{*}{ Difficulty eating } & None & 53336 & 89 & 38886 & 73 & 14450 & 27 \\
\hline & Some & 6866 & 11 & 686 & 10 & 6180 & 90 \\
\hline \multirow[t]{3}{*}{ Upper dental loss } & No teeth lost & 22387 & 37 & 17568 & 78 & 4819 & 22 \\
\hline & Some teeth lost & 26806 & 45 & 15390 & 57 & 11416 & 43 \\
\hline & All teeth lost & 11009 & 18 & 6614 & 60 & 4395 & 40 \\
\hline \multicolumn{8}{|l|}{ General Health Condition } \\
\hline \multirow{2}{*}{$\begin{array}{l}\text { Self-perception of } \\
\text { general health }\end{array}$} & Positive & 39141 & 65 & 29346 & 75 & 9795 & 25 \\
\hline & Negative & 21061 & 35 & 10226 & 49 & 10835 & 51 \\
\hline \multicolumn{8}{|l|}{ Use of dental services } \\
\hline \multirow{4}{*}{$\begin{array}{l}\text { Reason for the last dental } \\
\text { appointment }\end{array}$} & Prevention or check up & 14048 & 23 & 11551 & 82 & 2497 & 18 \\
\hline & Treatment & 11144 & 19 & 6859 & 62 & 4285 & 38 \\
\hline & Other & 464 & 1 & 278 & 60 & 186 & 40 \\
\hline & Not answered & 34546 & 57 & 20884 & 60 & 13662 & 40 \\
\hline \multirow{3}{*}{$\begin{array}{l}\text { Evaluation of the dental } \\
\text { service received }\end{array}$} & Positive & 23248 & 39 & 17520 & 75 & 5728 & 25 \\
\hline & Negative & 2408 & 4 & 1168 & 49 & 1240 & 51 \\
\hline & Not answered & 34546 & 57 & 20884 & 60 & 13662 & 40 \\
\hline \multicolumn{8}{|l|}{ Oral Self-care } \\
\hline \multirow[t]{3}{*}{ Use of dental floss } & Yes & 30699 & 51 & 23154 & 75 & 7545 & 25 \\
\hline & No & 28206 & 47 & 15841 & 56 & 12365 & 44 \\
\hline & Not answered & 1297 & 2 & 577 & 44 & 720 & 56 \\
\hline
\end{tabular}

nant of a positive perception of oral health rather than edentulism ${ }^{4,5,8,11,22}$. However, in the present study, the loss of some upper teeth seems to impact more negatively on self-perception of oral health than the total loss of the lower teeth. In addition, upper edentulism was shown to be a protective factor for positive perception of oral health $(\mathrm{OR}=0.89)$. In spite of the apparent incoherence of these results, the individuals seem to evaluate their oral health more positively when they do not present any tooth, than with the maintenance of few teeth in precarious conditions, in an insufficient number, and without access to prosthesis to ensure an effective and comfortable chewing ${ }^{20,21}$. Total edentulous patients were found also to be more prone to receive a low-complexity rehabilitative treatment with the use of total dentures, which can be collected by public health services compared to partial edentulous patients, whose dental treatment options are, for the most part, more complex and of difficult access ${ }^{24}$. These factors may induce partial edentulous patients to present greater functional and aesthetic impairments ${ }^{24}$ and consequently, greater dissatisfaction with oral health.

On the other hand, the relationship between self-perception of general and oral health is in agreement with the findings of the current re$\operatorname{search}^{11,20}$. In the present study, the prevalence of negative perceptions among individuals suffering from general health problems and biological frailty was higher ${ }^{6,11,20}$. Silva et al. ${ }^{11}$ consider this to be a complex and multifaceted relationship, since some unfavorable general health conditions may act as predisposing factors for oral health impairment, as well as deficient oral conditions may generate general health problems ${ }^{11,25}$. This result confirms the importance of studying co-morbidities and common risk factors ${ }^{6,26}$. In this sense, it is important to focus in the relationship between self-perception of oral health and general health condition in order to draw up effective preventive strategies ${ }^{11}$.

However, it should be noted that the presence of some chronic disease or a group of them, as a variable of interest, was not able to explain the 
Table 3. Reasons for self-perceived negative oral health according to the independent variables.

\begin{tabular}{lc}
\hline \multicolumn{1}{c}{ Variable } & $\begin{array}{c}\text { Oddis } \\
\text { Ratio (OR) }\end{array}$ \\
Difficulty eating & 1.00 \\
$\quad$ None & 5.81 \\
Some & \\
Upper dental loss & 1.00 \\
$\quad$ None tooth lost & 1.49 \\
$\quad$ Some teeth lost & 0.86 \\
All teeth lost & \\
Self-perception of general health & 1.00 \\
$\quad$ Positive & 1.91 \\
$\quad$ Negative & \\
Evaluation of the dental service & \\
received & 1.00 \\
$\quad$ Positive & 2.50 \\
$\quad$ Negative & \\
Reason for the last dental appointment & \\
$\quad$ Prevention, check-up & 1.00 \\
Treatment & 1.07 \\
Other & 1.21 \\
Use of Dental Floss & \\
$\quad$ Yes & 1.00 \\
No & 1.88 \\
\hline
\end{tabular}

self-perception of oral health, but only the general context of health. This finding indicates that general health situations transcends chronic conditions and reinforces that the complexity in the framework of health perceptions is much more involved with subjective issues than with objective clinical demands.

The reason and the evaluation of the last dental appointment were the only variables of the group of "use of dental services" that were related to the dependent variable. Visiting the dentist for check-up or prevention and positively evaluate appointment were self-referred factors of oral health protection. It is suggested that the explanation for this finding lies in the fact that routine visits to the dentist ${ }^{8,20}$ and good dental service $^{27,28}$ can minimize dental loss and improve oral condition, as well as empower patients with healthy living habits and the health-disease process, making them more confident about their status of oral health.

A similar condition can be observed regarding flossing. Individuals who floss regularly have a better self-perception of oral health ${ }^{6}$. The study emphasizes that the lack of knowledge and moti- vation to adopt preventive and care practices aggravates the oral health condition and compromises the self-perception of oral health ${ }^{4}$.

Moreover, it should be noted that the literature is rather vast and inconclusive in relation to factors that truly affect self-perception of oral health ${ }^{3-6,8,10-13,18-23}$. The only pattern that emerges from these studies is that most of the factors associated to sociodemographic, work characterize, lifestyle, health, and use of dental services by the individuals are related to the self-perception of oral health, however they do not contribute to the understanding of its variability. Given the diversity and the low power of association of the methods used to cross the factors of interest, the information obtained becomes little advantageous for the assertive decision making.

Through the feature selection test applied in the present study, it became possible to consider the pluralism of the social and health segments involved in the large database of the National Health Survey and to eliminate possible confounding or redundant factors, unraveling the variables that are truly important for the conformation of the self-perception of oral health. This condition becomes crucial for contributions that aim to increase the knowledge about self-perception of oral health in the Brazilian adult population, which can help supporting decision-making processes and redirection of oral health practices and resources.

\section{Limitations of the study}

As a limitation of the study, we highlight the subjectivity imbricated in the evaluation of self-perception of oral health, since it is susceptible to changes throughout life, day, week as a result of contextual conditions, psychological state experienced by the individual, as well as involving values and feelings not always expressed ${ }^{29}$. However, the subjectivity does not disqualify the relevance to guide policy and to plan decisions in health ${ }^{3,6}$.

In addition, because this is a cross-sectional study, it was not possible to establish a temporal relationship between the associations found.

\section{Conclusion}

The use of a multidimensional methodological basis was able to (re)design explanatory models for the self-perception of oral health of Brazilian adults and its results should be considered in the 
implementation, evaluation, and qualification of the national oral health network.

It is noteworthy that the determinants of the self-perception of oral health of Brazilians were difficulty feeding, use of dental floss, upper dental loss, self-perception of the general health condition, and reason and evaluation last dental appointment; and that factors related to sociodemographic and work characteristics, lifestyle, and presence of chronic diseases contributed little to the understanding of the variability of the self-perception of oral health of the adult population.

\section{Collaborations}

D Bordin delineated the study, interpreted the data and wrote the article. CB Fadel delineated the study and carried out the writing of the article. CB Santos conducted the statistical analysis, created the index for analysis and performed the interpretation of the data. CAS Garbin, SAS Moimaz and NA Saliba contributed writing and critical content review. 


\section{References}

1. Fonseca MGUP, Firmo JOA, Loyola Filho AI, Uchôa E. Papel da autonomia na auto-avaliação da saúde do idoso. Rev Saúde Pública 2010; 44(1):159-165.

2. Freitas DHM, Campos FCA, Linhares LQ, Santos CR, Ferreira CB, Diniz BS, Tavares A. Autopercepção de saúde e desempenho cognitivo em idosos residentes na comunidade. Rev Psiq Clin 2010; 37(1):32-35.

3. Thompson AG. The meaning of patient involvement and participation in health care consultations: a taxonomy. Soc Sci Med 2007; 64(6):1297-1310.

4. Agostinho MCMG, Campos ML, Silveira JLGC. Edentulismo, uso de prótese e autopercepção de saúde bucal entre idosos. Rev Odontol UNESP 2015; 44(2):7479 .

5. Carvalho C, Manso AC, Escoval A, Salvado F, Nunes C. Autopercepção da saúde bucal em idosos de uma população urbana em Lisboa, Portugal. Rev Saúde Pública 2016; 50:53.

6. Gabardo MCL, Moysés ST, Moysés SJ. Autopercepção de saúde bucal conforme o Perfil de Impacto da Saúde Bucal (OHIP) e fatores associados: revisão sistemática. Rev Panam Salud Publica 2013; 33(6):439-445.

7. Johnstone MJ, Kanitsaki O. Engaging patients as safety partners: some considerations for ensuring a culturally and linguistically appropriate approach. Health Policy 2009; 90(1):1-7.

8. Luchi CA, Peres KG, Bastos JL, Peres MA. Desigualdades na autoavaliação da saúde bucal em adultos. Rev Saúde Pública 2013; 47(4):740-751.

9. Martins AMEBL, Barreto SM, Pordeus IA. Objective and subjective factors related to self-rated oral health among the elderly. Cad Saúde Pública 2009; 25(12):421-435.

10. Sanders AE, Spencer AJ. Social inequality in perceived oral health among adults in Australia. Aust N Z J Public Health 2004; 28(2):159-167.

11. Silva DD, Held RB, Torres SVS, Sousa MLR, Neri AL, Antunes JLF. Autopercepção da saúde bucal em idosos e fatores associados em Campinas, SP, 2008-2009. Rev Saúde Pública 2011; 45(6):1145-1153.

12. Silva DD, Souza MLR, Wada RS. Saúde bucal em adultos e idosos na cidade de Rio Claro, São Paulo, Brasil. Cad Saúde Pública 2004; 20(2):626-631.

13. Silva SRC, Castellano Fernandes RA. Autopercepção das condições de saúde bucal por idosos. Rev Saude Publica 2001; 35(4):349-355.

14. Desalvo KB, Muntner P. Discordance between physician and patient self-rated health and all-cause mortality. Ochsner J 2011; 11(3):232-240.

15. Larsson IE, Sahlsten MJ, Sjostrom B, Lindencrona CS, Plos KA. Patient participation in nursing care from a patient perspective: a Grounded Theory study. Scand J Caring Sci 2007; 21(3):313-320.

16. Bruin A, Picavest HSJ, Nossikov A, editors. Health interview surveys: toward international harmonization of methods and instruments. Copenhagen: WHO; 1996.

17. Jylha M. What is self-rated health and why does it predict mortality? Towards a unified conceptual model. Soc Sci Med 2009; 69(3):307-316.

18. Martins AMEBL, Barreto SM, Pordeus IA. Objective and subjective factors related to self-rated oral health among the elderly. Cad Saúde Pública 2009; 25(2):421-435.
19. Szwarcwald CL, Malta DC, Pereira CA, Vieira MLFP, Conde WL, Souza Júnior PRB, Damacena GN, Azevedo LO, Silva GA, Theme Filha MM, Lopes CS, Romero DE, Almeida WS, Monteiro CA. Pesquisa Nacional de Saúde no Brasil: concepção e metodologia de aplicação. Cien Saude Colet 2014; 19(2):333-342.

20. Andrade FB, Lebrão ML, Santos JLF, Duarte YAO, Teixeira DCT. Factors related to poor self-perceived oral health among community-dwelling elderly individuals in São Paulo, Brazil. Cad Saúde Pública 2012; 28(10):1965-1975.

21. Martins AMEBL, Barreto SM, Silveira MF, Santa-Rosa TTA, Pereira RD. Self-perceived oral health among Brazilian elderly individuals. Rev Saúde Pública 2010; 44(5):912-922.

22. Nico LS, Andrade SSCA, Malta DC, Pucca Júnior GA, Peres MA. Self-reported oral health in the Brazilian adult population: results of the 2013 National Health Survey. Cien Saude Colet 2016; 21(2):389-398.

23. Cascaes AM, Peres KG, Peres MA. Periodontal disease is associated with poor self-rated oral health among Brazilian adults. J Clin Periodontol 2009; 36(1):25-33.

24. Martins AB, Dalberto CS, Hugo FN. Associação entre a presença de restos radiculares e a autopercepção de saúde bucal em idosos. Cien Saude Colet 2015; 20(12):3669-3679.

25. Araújo PC, Garbin CAS, Moimaz SAS, Saliba NA, Arcieri RM. Perception and Attitude About Systemic Health and Periodontal Disease Among Dentistry Undergraduates. Oral Health Prev Dent 2013; 11(4):383-388.

26. Saliba NA, Moimaz SAS, Marques JAM, Prado RL. Elderly caregivers profile and oral health perception. Interface (Botucatu) 2007; 11(21):39-50.

27. Bordin D, Fadel CB, Moimaz SAS, Garbin CAS, Saliba NA. Comparative study of satisfaction of users and health professionals with the public dental service. Cien Saude Colet 2017; 22(1):151-160.

28. Moimaz SAS, Lima AMC, Garbin CAS, Corrente JE, Saliba, NA. Avaliação do usuário sobre o atendimento odontológico no Sistema Único de Saúde: uma abordagem à luz da humanização. Cien Saude Colet 2016; 21(12):3879-3887.

29. Moura C, Gusmão ES, Santillo PMH, Soares RSC, Coelho RS, Cimões R. Autoavaliação da saúde bucal e fatores associados entre adultos em áreas de assentamento rural, Estado de Pernambuco, Brasil. Cad Saude Publica 2014; 30(3):611-622.

Article submitted 12/05/2018

Approved 18/02/2019

Final version submitted 20/02/2019 